\title{
Climate potential and tourist demand in Catalonia (Spain) during the summer season
}

\author{
Ma Belén Gómez-Martín* \\ Department of Physical Geography and Regional Analysis, Faculty of Geography and History, \\ University of Barcelona, C/ Baldiri Reixac s/n, Barcelona 08028, Spain
}

\begin{abstract}
This article shows how the study of climate-preference demand (through surveys, interviews, behavior observation, etc.) is a key factor in the development of a catalog of types of weather suitable for tourism, which can then be applied to present or future climatic scenarios with the goal of evaluating climate-tourism potential. The proposal utilizes the weather-types method of Besancenot, Mounier and de Lavenne, which incorporates 7 climate variables and comfort indexes relevant to general tourism activities, to assess the spatial and temporal distribution of climate resources for tourism in Catalonia (Spain). The results were compared with the tourist's reality in the area of study, by considering the number of visitors and the occupation rate of tourist lodging. The study of present climate suitabilities and of tourists' behavior discloses several uncertainties that should be examined; however, at the same time, these suggest several management strategies which, if adopted, could be immediately beneficial for the tourist sector. At present, in the Spanish and Catalan case, the opportunities offered by climate-tourist resources are not being fully utilized. The periods and places identified as climatically suitable for tourism are greater than the periods and spaces actually used by tourists. This is why the agents and operators in the market must act on the demand, in consideration of the geographic-tourist space, and on the supply to maximize use of the climate resource.
\end{abstract}

KEY WORDS: Weather $\cdot$ Climate $\cdot$ Tourism potential $\cdot$ Demand $\cdot$ Climate change $\cdot$ Catalonia

\section{INTRODUCTION}

Research on the impact that climate change can have on the Spanish tourist sector is in its initial phase. The tourist system is made up of 4 fundamental elements (the geographical-tourist space, tourist demand, supply, and the operators and agents in the market), and it is logical to suppose that all of these will directly or indirectly feel the effects of climate change. It is natural to suppose that the first element to be affected by this phenomenon would be the geographical-tourist space and, thereafter, demand, supply, and the operators and agents in the market. Studies show that the loss of functionality and attractiveness in leisure and recreation areas can cause changes in the flow and behavior of tourists (Perry 2000, 2001, 2005, Agnew \& Viner 2001, Maddison 2001, Lise \& Tol 2002), generating a drag effect on the other elements in the system (Lise \& Tol
2002, Scott 2003). In any case, this 'logical' sequence can be altered by the multitude of factors that can affect demand, adjusting and subtly changing expected behavior. In this sense, I believe that tourist demand is a key element in the search for responses that include the adaptation to and/or mitigation of possible changes. The study of demand preferences, sensitivity, tolerance level, behavior, and ability to adapt can all be decisive factors in proposing solutions.

This article shows how the study of climate preference is a key factor for the preparation of a catalog of types of weather that are suitable for tourism, which could then be applied to present or future climatic scenarios with the goal of evaluating the effects of climate on tourism potential. The geographical area selected for study is the Autonomous Community of Catalonia (Spain). The analysis of climate suitability and tourist behavior done here shows that a number of aspects of 
the question remain uncertain, but at the same time, it also offers some essential ideas for management strategies that would improve opportunities for the tourism sector both now and in a future climate-change scenario.

\section{STUDY AREA}

Tourism is considered one of the primary economic activities in the world, representing more than $10 \%$ of the world's GDP and creating more than 115 million direct jobs. According to estimates from the WTO (World Tourism Organization 2004), in 2003 there were 691 million international tourist arrivals. Tourism figures for 2003 show that Spain is still in a privileged position with respect to the rest of the world, competing with France and the United States for the position of the number-one tourist destination in the world. Foreign visitors crossing borders into Spain are estimated at 82.6 million, of whom 52.5 million are estimated to be tourists in the strict sense of the term (Instituto de Estudios Turísticos 2004a). In addition to tourism from outside Spain, there is also domestic tourism, which is considerable and growing steadily. Statistics from FAMILITUR (Instituto de Estudios Turísticos 2004b) estimate that Spaniards took 44.9 million tourist trips in 2003 (short trips to second homes are estimated at 84.3 million, which, when added to the trips noted above, shows Spaniards take an estimated total of 129.2 million trips), most of them to destinations inside Spain.

Catalonia is one of the most important regions for tourism in Spain. It receives more than 14.5 million foreign tourists and around 5 million visitors from the rest of Spain each year, while the Catalans themselves account for a large internal tourist sector which generates around 15 million journeys with overnight stays. These data highlight the importance of a sector that has a turnover of more than 12.3 billion, amounting to approximately $10 \%$ of the GDP for Catalonia (Estudis de Turisme de Catalunya 2004). From the supply perspective, Catalonia has a large number of enterprises and establishments that make up a highly fragmented tourism sector. The diversity and abundance of the region's resources have led to very different processes of tourism development and a variety of offerings (sun and surf, culture, snow, rural, golf, boating, nature, ...), forming an asymmetric tourist map in which we find areas that are used for tourism in varying degrees and with offerings that are very different in terms of quality (Fig. 1, Table 1).

\section{METHODS AND DATA}

\subsection{General approximation}

When speaking of weather or climate, we refer to a set of parameters that appear simultaneously, interacting and influencing various aspects of the natural, human, and economic environment. These parameters show their effect on people in physical or mechanical, physiological, and psychological ways, or a combination of all of them (De Freitas 2001). Different individuals do not evaluate the results of these influences in the same way, which makes it necessary to introduce a

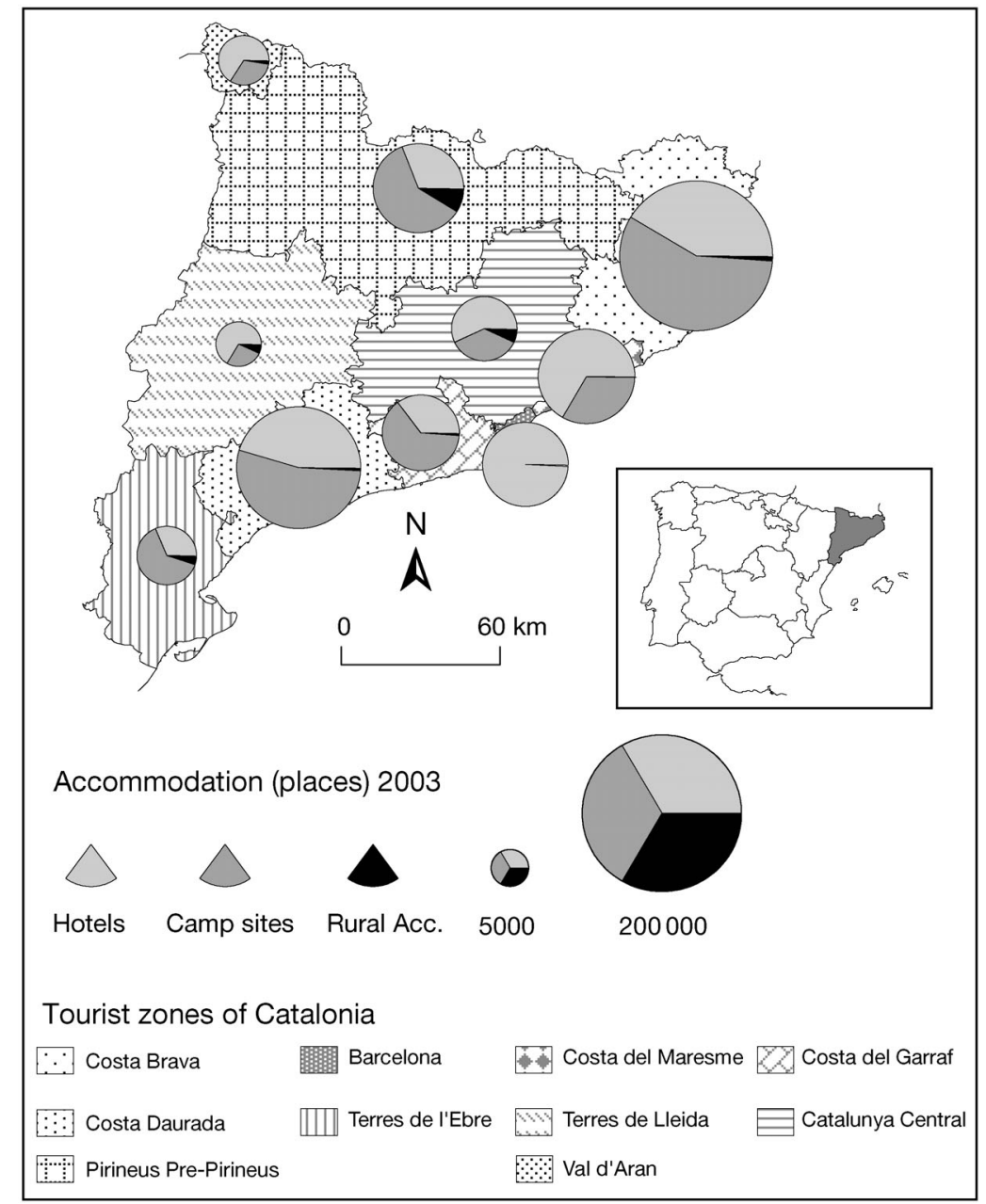

Fig. 1. Types of accommodation offered (in number of places) in 2003 in Catalonia, Spain. Source: Direcció General de Turisme 
Table 1. Overnight stays according to the origin of tourists and destination in 2003. Statistics do not include second homes or overnight stays in second homes. Source: Direcció General de Turisme

\begin{tabular}{|lrrr|}
\hline Tourist zone & Foreign & Spanish & Catalonian \\
\hline Costa Brava & 44921000 & 3452000 & 6069000 \\
$\begin{array}{l}\text { Costa Daurada and } \\
\text { Terres de l'Ebre }\end{array}$ & 14701000 & 9222000 & 4257000 \\
$\begin{array}{l}\text { Pirineus Pre-Pirineus } \\
\text { and Val d'Aran }\end{array}$ & 1854000 & 907000 & 3237000 \\
Catalunya Central & 1541000 & 1946000 & 922000 \\
Costa del Garraf & 3530000 & 1667000 & 1090000 \\
Costa del Maresme & 10479000 & 1113000 & 613000 \\
$\begin{array}{l}\text { Terres de Lleida } \\
\text { Barcelona }\end{array}$ & 429000 & 1177000 & 988000 \\
& 22290000 & 9675000 & 550000 \\
\hline
\end{tabular}

complex explanatory variable: perception. Thus we can conclude that the study of the present or future tourism potential of climate should incorporate the subjective point of view of the consumer-tourist (through surveys, interviews, behavior observation, etc.), getting away from the traditional objective methods used in evaluations of other tourist resources and in the original studies of tourism climatology (GómezMartín 2005). In the latter case we are referring to certain climate indexes (e.g. those of Burnet, Poulter, Davis and Hughes) which, although they do simplify the calculations, are inadequate. They are unrealistic, fail to take account of parameters that are important in the normal development of tourism and do not consider the preferences shown by consumers.

All evaluations of a territory's climate-tourism potential should answer 2 preliminary questions. On the one hand, they should try to define the ideal or the climatemeteorological preferences of the tourists, and on the other they should provide a method that makes it possible to objectively compare reality to that ideal and to present the results in a simple and comprehensible way. In an exhaustive analysis of existing proposals (Gómez-Martín 2000), it can be seen that the model of types of weather as proposed by Besancenot et al. (1978) and Besancenot $(1985,1991)$ is a good option, since it lends itself to the incorporation of subjective nuances, and thus to the comparison of ideal and real weather. To define the tourist's ideal climate, one assumes a priori that it should provide basic levels of comfort, enjoyment, and safety (Besancenot 1991). The parameters we can use for evaluation are daily sunshine (hours), duration of daily precipitation (hours), maximum daily air temperature $\left({ }^{\circ} \mathrm{C}\right)$, average wind speed at 13:00 h $\left(\mathrm{m} \mathrm{s}^{-1}\right)$, and finally the Siple \& Passel (1945) thermo-anemometric index $\left(\mathrm{kcal} \mathrm{m}^{-2} \mathrm{~h}^{-1}\right)$ and Thom's thermo-hygrometric index $\left({ }^{\circ} \mathrm{C}\right)$, both calculated at the time of maximum air temperature. Although it might be interesting to consider optimal thresholds for each type of tourism, the study presented here focuses on tourism in general (during summer), since it is believed that the tourist seldom pursues only one type of tourist activity, but rather is interested in a variety of activities for which he or she requires several minimal thresholds.

The application of the Besancenot's method began with the analysis of the weather in Catalonia (in summer), which made it possible to establish frequent weather types: sunny weather, weather with partial cloud cover, hot sultry weather, very hot sultry weather, cool weather, weather with short periods of rain, weather with strong winds, rainy weather, rainy and windy weather, etc. With this information, a pretest was designed and administered. In the pretest, questions were asked, indirectly and in different ways, about the previously defined weather types (for example, 'Which weather type on the list do you think is the best for doing tourism?' or 'Which weather type on the list do you think is the most unpleasant for doing tourism?' or 'Can you put these weather types in order from most favourable to the least favourable for summer tourism?', etc.). The results were useful to establish the 'preferences' of the tourists approximately and define 6 favourable weather types. The unfavourable weather types were gathered in 2 types.

Using this information a survey was prepared for the purpose of corroborating the findings of the pretest and defining thresholds for weather types. The choice of a quantitative-analysis technique (based on statistical methods of gathering, analyzing and processing data whose results are extrapolatable according to the parameters defined in the technical description Table 2) allowed us to establish several optimal thresholds for the area of study and led us to distinguish 8

Table 2. Technical specifications of survey in 1998

\begin{tabular}{|ll|}
\hline Methodology & $\begin{array}{l}\text { Quantitative } \\
\text { Personal questionnaires } \\
\text { Population }\end{array}$ \\
& $\begin{array}{l}\text { Tourists (foreign, Spanish and } \\
\text { Catalan tourists) over 14 yr } \\
\text { that visit Catalonia (infinite } \\
\text { population) }\end{array}$ \\
Spatial area & Catalonia \\
System of validation & Known groups \\
& Random probe \\
Type of questionnaire & Structured \\
Method of selection & Random route \\
Sample size & 402 personal questionnaires \\
Type of sample & Stratified random of Bernouilli \\
Sampling error & \pm 5 \\
Confidence level & $95.5 \%(2 \sigma)$ \\
Variance $(\mathrm{p}, \mathrm{q})$ & $\mathrm{p}=50 \%, \mathrm{q}=50 \%$ \\
Period & $1 \mathrm{Apr}-30$ Nov
\end{tabular}


types of weather for the season under consideration in this case summer - from which we could proceed to the evaluation of the potential (i.e., contrast the ideal with reality; Gómez-Martín 2004). Of these 8 types of weather (Table 3), the first 6 lend themselves well to tourism, although to different degrees (Type 1: very good, sunny weather; Type 2: fine weather with partial cloud cover; Type 3: fine, hot, sultry weather; Type 4: fine, cool weather; Type 5: fine weather with short periods of rain; Type 6: fine weather with strong winds); the last 2 appear to present obstacles to outdoor tourism (Type 7: unfavorable weather; Type 8: bad weather). The catalog of types for Catalonia differs from that proposed by Besancenot for these latitudes in several aspects. The tourists who visit the geographical area covered by the study express a strong demand for sunshine and are tolerant of high temperatures. They are intolerant of wind, but reasonably tolerant of precipitation, as long as the periods of rainfall are short. As a result of these findings we have readjusted the thresholds of the various parameters considered and put the types of favorable weather in order of preference as defined by the tourists interviewed.

\subsection{The survey}

In this section we show the questions included in the survey, why the parameters considered were chosen, the responses given by the survey respondents, and the justification for the thresholds used in the classification of the types of summer weather in Catalonia. Each of the elements included in the questionnaire is analyzed; we also explain the thresholds used in the 2 comfort indexes that are used.

\subsubsection{Daily sunshine}

Daily sunshine measured in hours is considered in the classification of summer weather types in Catalonia because of the influence that it has upon the feelings of enjoyment and comfort that the tourist experiences, although it is worth adding that it is not a limiting element of tourist activity (Winslow \& Herrington 1935, Auliciems 1976, 1978, Escourrou 1980, Besancenot 1991). Furthermore, sunshine is, together with precipitation and wind, one of the elements that are most clearly perceived by the tourist. Therefore, the delimitation of thresholds for this parameter can be based on the preferences shown by tourists in surveys (Terjung 1966, Campbell \& Beets 1977, Cunningham 1979).

Since the pretest showed that directly asking about the hours of sunshine per day and how they would define the day's weather confused the respondents, because they had to try to calculate how many daylight hours there were in a day, etc., it was decided to ask this question using the so-called sun fraction. The sunlight fraction is the relationship, converted into a percentage, of the duration of sunlight measured against the measurement that would have been achieved if the sun had shone without interruption. For the calculation of the sunlight fraction, it is indispensable to first know the duration of the day (daylight hours) or the maximum possible sunlight. The duration of the day is variable in space and in time and depends on the declination of the sun and the latitude of the location. The solar declination $(\delta)$ is defined as the angle formed by the rays coming from the sun and the equatorial plane. The data corresponding to solar declination (in degrees) for each day of the year can be calculated with sufficient precision according to Cooper's equation, where $n$ is the day of the year (which takes the value 1 on January 1 and the value 365 on December 31):

$$
\delta=23.45 \sin \{360[(284+n) / 365]\}
$$

By knowing the declination $(\delta)$ and the latitude (L), it is possible to determine the duration of the day (in hours) using the following formula:

$$
N=0.13333[\arcsin (-\tan L \times \tan \delta)]
$$

To establish different thresholds for this, the maximum daily sunshine was calculated for the summer

\begin{tabular}{|c|c|c|c|c|c|c|c|}
\hline & $\begin{array}{l}\text { Daily sunshine } \\
\text { (h) }\end{array}$ & $\begin{array}{c}\text { Cloud cover, } \\
N_{\mathrm{b}} \text { (octas) }\end{array}$ & $\begin{array}{l}\text { Daily precip. } \\
\text { (h) }\end{array}$ & $\begin{array}{l}\text { Max. daily } \\
\text { temp }\left(\mathrm{C}^{\circ}\right)\end{array}$ & $\begin{array}{l}\text { Wind speed } \\
\left(\mathrm{m} \mathrm{s}^{-1}\right)\end{array}$ & $\begin{array}{c}P \\
\left(\text { kcal m}^{-2} \mathrm{~h}^{-1}\right)\end{array}$ & $\begin{array}{l}\text { THI } \\
\left({ }^{\circ} \mathrm{C}\right)\end{array}$ \\
\hline Type 1 & $\geq 11$ & $\leq 2 / 8$ & 0 & 22 to $<28$ & $<8$ & $\geq 50$ & 15 to $<28.5$ \\
\hline Type 2 & 5 to $<11$ & $5 / 8>N_{\mathrm{b}}>2 / 8$ & 0 & 22 to $<28$ & $<8$ & $\geq 50$ & 15 to $<28.5$ \\
\hline Type 3 & $>5$ & $<5 / 8$ & 0 & 28 to $<33$ & $<8$ & $\geq 50$ & 20 to $<28.5$ \\
\hline Type 4 & $>5$ & $<5 / 8$ & 0 & 16 to $<22$ & $<8$ & $\geq 50$ & 15 to $<26.5$ \\
\hline Type 5 & $>5$ & $<5 / 8$ & 0 to $<1$ & 16 to $<33$ & $<8$ & $\geq 50$ & 15 to $<28.5$ \\
\hline Type 6 & $>5$ & $<5 / 8$ & 0 & 22 to $<33$ & 8 to $<12$ & $\geq 50$ & 15 to $<28.5$ \\
\hline Type 7 & \multicolumn{7}{|c|}{ All weather types with the exception of types $1,2,3,4,5,6$ and 8} \\
\hline Type 8 & $\leq 5$ & $\geq 5 / 8$ & $>3$ & These & ameters can a & opt any value & \\
\hline
\end{tabular}

Table 3. Description of summer weather types in Catalonia. $P$ : cooling power of air; THI: thermo-hygrometric index 
season in the area of analysis, which for us, as for previous authors (Gómez-Martín 2000, 2003), covers the period from April to November. Bearing these considerations in mind, 2 questions were developed, offering various numerical values for each one. The results of the first question ('During the summer, do you consider that it was 'a good sunny day' when the sun shone for at least...?') show that between 27.3 and $37.3 \%$ of tourists that visit Catalonia think that in summer it has been a 'good sunny day' when the sun has shone for at least $77 \%$ of daylight hours $\left(11 \mathrm{~h} \mathrm{~d}^{-1}\right)$ with a probability of $95.5 \%$ (Fig. 2). In the same way, the extrapolation of the responses to the second question ('During the summer, do you think that there has been a 'complete lack of sun' when the sun shines for only...?') shows that between 43.3 and $53.3 \%$ of tourists who visit Catalonia think that in summer a day shows 'a complete lack of sun' when the sun shines only $35 \%$ of the day $\left(5 \mathrm{~h} \mathrm{~d}^{-1}\right)$ with a probability of $95.5 \%$ (Fig. 3). The results show that tourists who visit Catalonia show high expectations in terms of sun, possibly in accordance with a preconceived image about Spain and the climate of the place they are visiting, an image that is commonly advertised by tourism marketers (GómezMartín 1999a,b).

Given that, in this work, sun is not considered a factor that impedes outdoor activities, a threshold of $11 \mathrm{~h}$ of sun per day or more $(I \geq 11)$ has been established as the minimum for the weather type that perfectly lends itself to outdoor tourist activity (Type 1); for those types of weather that lend themselves to tourist activities with good weather although with some inconvenience (Types 3, 4, 5 and 6), the minimum has been reduced to $5 \mathrm{~h}$ of sun per day $(I>5)$; for Type $2(\operatorname{good}$ weather with partial cloud cover), the threshold has been set at $5<I<11$. For Type 8 (very bad weather), the threshold is under $5 \mathrm{~h}(I<5)$. Since not all of the observatories have sun recorders, we propose an indirect approximation for that parameter using the cloudiness observed at midday, measured in octas of cloud cover $\left(N_{\mathrm{b}}\right)$. Angstrom's formula $\left(r+100 N_{\mathrm{b}} / 8=100\right.$, where $r$ designates the sunshine fraction) allowed us to use an approximation of the thresholds established previously, leaving discontinuities at 2 and 5 octas of cloud cover (Table 3).

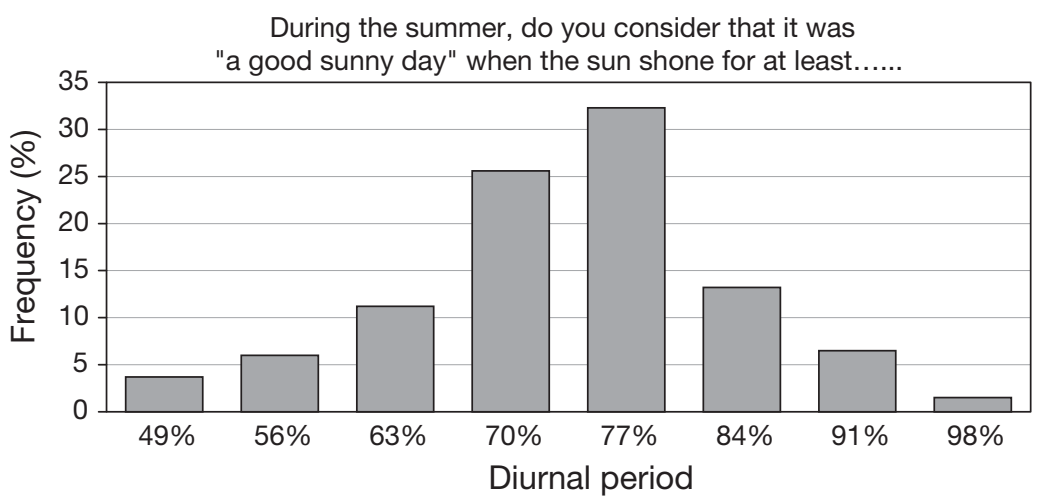

Fig. 2. Survey results: 'Good sunny day'

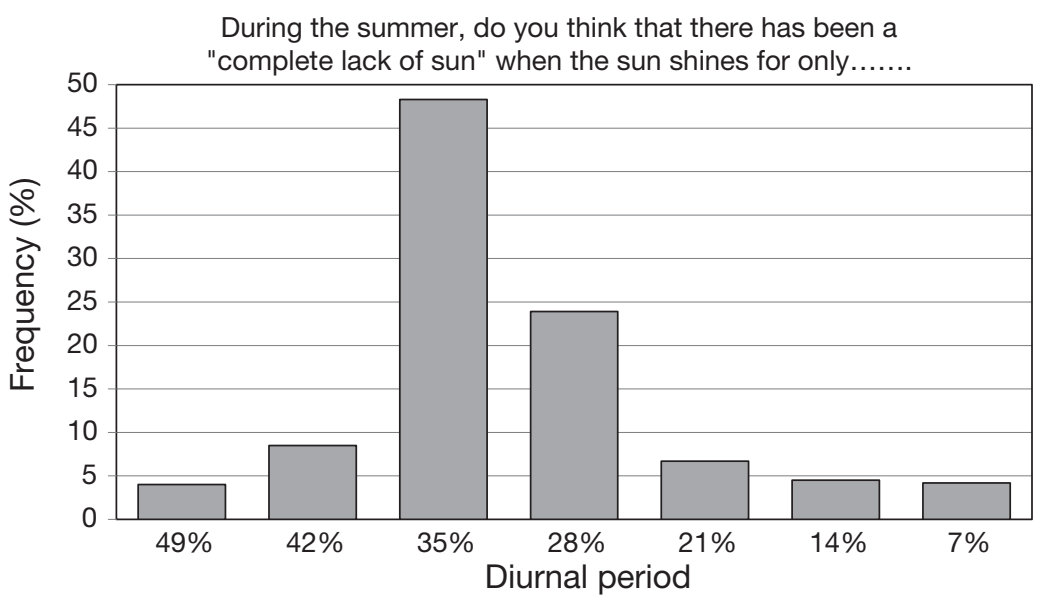

Fig. 3. Survey results: 'Complete lack of sun'

\subsubsection{Duration of daily rainfall}

The effect of precipitation on the enjoyment and safety of tourist activities is well known, especially when these activities are pursued outdoors. Precipitation, when it goes over certain thresholds, can act as a limiting factor capable of eclipsing all of the other favorable factors and creating a totally negative impression of the weather (Campbell \& Beets 1977, Cunningham 1979, Besancenot 1991).

This influence can be analyzed on the basis of the amount of rainfall or of the duration of each precipitation episode; however, in tourism climatology, 'the height in millimeters of the water collected in the rain gauge has only a secondary interest compared to the way in which rain falls, the frequency of showers, the duration of downpours, and the time of day at which they occur.' (Besancenot 1991, p. 32). With this in mind, we decided to take into account the variable 'duration in hours' in the classification of the types of summer weather in Catalonia. Since the precipitation that specifically impedes tourist activity occurs during periods of time when people are 
engaged in recreational activities, we considered the length of these episodes during those periods. The survey confirms that $82.6 \%$ of the tourists interviewed (extrapolating the results between 77.6 and $87.6 \%$ with a probability of $95.5 \%$ ) consider soft, continuous rain during the recreational period more annoying for tourist activities than short, heavy downpours that fall during the activity period or at night, or than soft, continuous rain during the night.

The tourist was then asked: 'How long does the precipitation episode during the recreation period have to last for you to consider that the day has been totally ruined for tourism activities?' Between 57.2 and $67.2 \%$ of the tourists that visit Catalonia believe that a summer day is 'totally ruined' for tourism activities when the precipitation lasts more than $3 \mathrm{~h}$ during the period of recreational activity, with a probability of $95.5 \%$.

Sometimes a precipitation episode does not mean the day is totally ruined for tourism. Many times, depending on the duration of the episodes and the quantity of rainfall, a day can still be partially used for outdoor tourist activities; this is what is understood as 'a day with weather that is acceptable for tourism.' Using this approach, the survey asked the tourist about 'maximum durations you are ready to accept during the period of recreational activity and still consider that the day was acceptable from the standpoint of tourism.' The responses showed that between 64.7 and $74.7 \%$ of tourists think that in the summer a day is acceptable when precipitation lasts less than $1 \mathrm{~h}$ during the period of recreational activity, with a probability of $95.5 \%$.

Since the National Institute of Meteorology has provided data that is only precise to the day, we have had to introduce a small modification and ultimately focus on thresholds not for the period of recreational activity but instead for the whole $24 \mathrm{~h}$ period. In this way, weather Types 1, 2, 3, 4, and 6 do not include precipitation. Type 5 (good weather with a brief rainy period) includes precipitation with a duration of less than $1 \mathrm{~h}$ during the $0-24 \mathrm{~h}$ period. Finally, Type 8 (bad weather) occurs when precipitation lasts longer than $3 \mathrm{~h}$ (Table 3).

\subsubsection{Maximum daily air temperature}

The maximum daily air temperature expressed in ${ }^{\circ} \mathrm{C}$ has a large influence on the tourist's feelings of enjoyment and comfort, which is why it is included in the classification of the types of weather for Catalonia. The maximum daily air temperature is considered the most important for the tourist, given that this temperature typically occurs during the central part of the recreational activity period.
Air temperature is important not only for the influence that it has on the tourist's feeling of enjoyment, but also for its influence on the physiological processes of living beings. Tourism climatology has tried to specify, from a bio-climatic point of view, the temperature thresholds that are most favorable for people in general and tourists in particular.

Several studies (Escourrou 1980, Besancenot 1991) agree that the optimum maximum air temperatures correspond to $16-33^{\circ} \mathrm{C}: 16^{\circ} \mathrm{C}$ corresponds to the point at which anti-cold mechanisms come into play and at which an inactive (at that moment) human dressed in light clothing begins to feel a sensation of coolness; $33^{\circ} \mathrm{C}$ (the average temperature of bare skin) corresponds to the point at which the organism, in similar conditions, runs the risk of not being able to transmit sensible heat to the external environment.

Since tourism climatology establishes the optimal threshold of maximum air temperature for general tourist activity and since the proposed interval $\left(16-33^{\circ} \mathrm{C}\right)$ is too wide to use in the method establishing types of weather, it was decided to divide the summer season into 3 ranges $\left(16-22,22-28\right.$ and $\left.28-33^{\circ} \mathrm{C}\right)$ and present them to tourists, asking them 'Which range is best and which is worst for tourism?' The extrapolation of the results for the first question showed that between 69.6 and $79.6 \%$ of the tourists who visit Catalonia consider the maximum summer temperature range that is ideal for tourism to be $22-28^{\circ} \mathrm{C}$, with a probability of $95.5 \%$. At the same time, between 50.5 and $60.5 \%$ of tourists think that the maximum air temperature range that is least favorable to tourism is $16-22^{\circ} \mathrm{C}$, with a probability of $95.5 \%$.

The difficulty of asking about air-temperature thresholds lies, among other things, in the subjectivity that is part of the very process of perceiving sensations. However, experience and, in this case, the surveys indicate that in spite of subjectivity more or less generalized preferences do exist. It has been possible to show that a high percentage of the tourists that visit Catalonia like warm-but-moderate air temperatures (between 22 and $28^{\circ} \mathrm{C}$ ); it has also been possible to show that, at least for the summer season, tourists do not care for cooler air temperatures and show moderate acceptance for extremely high temperatures.

The results obtained are not far from those reflected in other studies, although the division into 3 temperature ranges has provided more detailed information about tourists' preferences in weather for recreational activities. For example, the survey results show hot weather (Type 3, with air temperature between 28 and $33^{\circ} \mathrm{C}$ ) as more desirable than cool weather (Type 4 , with air temperatures between 16 and $22^{\circ} \mathrm{C}$ ). Types 1

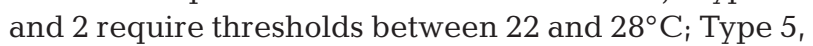
good weather with a brief rainy period, allows maxi- 
mum air temperatures between 16 and $33^{\circ} \mathrm{C}$; Type 6 , good weather with strong wind, has maximum air temperatures between 22 and $33^{\circ} \mathrm{C}$; and finally the types of unfavorable and bad weather (Types 7 and 8) can show air temperatures in or out of the optimum threshold range (Table 3).

\subsubsection{Wind speed}

Wind, understood as the horizontal movement of air, has a considerable influence on the sensation of enjoyment, comfort, and security that a tourist experiences. This influence is exercised through the 2 parameters that define it: direction (which usually includes several characteristics in terms of temperature and hygrometric content) and speed. In this way, wind can be a prejudicial or beneficial element for tourist activities, not only due to the direct effect derived from its force or pressure, but also because of the changes that it can produce in the other atmospheric elements.

Since indirect influences will be analyzed through a comfort index and given that the tourist is more sensitive to mechanical action, this is the only element that we have included in the survey. Since the information supplied by National Institute of Meteorology with respect to the wind parameter in the first-order meteorological observatories was quite deficient, we have had to adapt the series provided by this organization to our interests (specifying the information for the period of recreation activity), taking the daily wind speed data at 13:00 $\mathrm{h}$ for analysis. As was shown in the pretest, asking directly about wind speed did not produce satisfactory results, as it was difficult for the tourist to identify wind speed in a real situation. It was decided to use the Beaufort scale, which identifies the force of the wind using the observation of the effects that it has on objects that oppose the movement of the air mass. Even if this scale does not provide a high level of precision, its simplicity, adaptability to real-life situations, and the ease with which it can be understood by the tourist make it extremely useful for our purpose.

Of the 13 levels (0 to 12) that the Beaufort scale offers, we have only used the first 9 (0 to 8$)$, since the rest represent too high a risk to tourists' safety. The results of the questions 'what is the maximum level of wind that you would tolerate during tourist activities in summer' show that between 37.8 and $47.8 \%$ of the tourists that visit Catalonia say that the most that they would put up with during their recreation activities in summer would be wind level 4 (5.5 to $7.9 \mathrm{~m} \mathrm{~s}^{-1}$ ), with a probability of $95.5 \%$.

Since we are talking about maximum levels, we chose the upper limit of the interval as our threshold. In this way, we establish that the types of weather that most lend themselves to tourist activities (Types 1 to 5) should have wind velocities that are lower than $8 \mathrm{~m} \mathrm{~s}^{-1}$. Type 6 (good weather with strong wind) can have velocities between 8 and $12 \mathrm{~m} \mathrm{~s}^{-1}$; finally, unfavorable and bad conditions (Types 7 and 8) can be, though not necessarily are, higher than the maxima seen in windy periods (that is, velocities of $12 \mathrm{~m} \mathrm{~s}^{-1}$ or more) (Table 3 ).

In terms of wind, it can be said that tourists that visit Catalonia show a greater sensitivity than those who visit other areas (note that the fullest classes after wind level 4 are those that correspond to wind levels 3 and 2). This greater sensitivity has also been observed in the marginal comments made by tourists interviewed and in responses to questions in the pretest. A large number indicated that the most irritating element during tourist activities was wind, even more than precipitation. This has led us to classify the windy weather type (Type 6) as more unfavorable than the type of weather that includes a brief rainy period (Type 5).

\subsubsection{Thermo-anemometric index}

The Siple \& Passel index (1945) evaluates the cooling power of air $(P)$ per unit of time $\left(\mathrm{kcal} \mathrm{m}^{-2} \mathrm{~h}^{-1}\right)$. The calculation has been done at the time of maximum heat using the daily maximum air temperature value in ${ }^{\circ} \mathrm{C}$ $(t)$ and wind speed at 13:00 h in $\mathrm{m} \mathrm{s}^{-1}(v)$, using the following formula:

$$
P=\left(10 v^{0.5}+10.45-v\right)(33-t)
$$

Since this parameter is not included in the survey, we will justify the limits chosen for the classification here. It was assumed that the cooling power of air cannot be set at less than $50 \mathrm{kcal} \mathrm{m}^{-2} \mathrm{~h}^{-1}$, since it is estimated that 'this is the threshold under which discomfort increases dangerously since when the external temperature is above $33^{\circ} \mathrm{C}$, the normal temperature of naked skin, the body is incapable of directly transferring to the air its excess calories' (Besancenot 1991, p. 36). Thus all kinds of weather suitable for tourism should show values greater than $50 \mathrm{kcal} \mathrm{m}^{-2} \mathrm{~h}^{-1}$, although, in fact, relaxing conditions are found in the interval 300 to $599 \mathrm{kcal} \mathrm{m}^{-2} \mathrm{~h}^{-1}$.

\subsubsection{Thermo-hygrometric index}

This comfort index calculated by Thom (1959) gives the temperature felt by our bodies in ${ }^{\circ} \mathrm{C}$ depending on the relative humidity of the air at 13:00 $\mathrm{h}$ and the maximum daily air temperature. The formula is as follows:

$$
\mathrm{THI}=T_{\mathrm{x}}-\left[0.55-(0.0055 U \%)\left(T_{\mathrm{x}}-14.5\right)\right]
$$


in which $T_{\mathrm{x}}$ is the maximum air temperature in ${ }^{\circ} \mathrm{C}$ and $U \%$ is the relative humidity at the time of maximum air temperature.

Since this parameter was not included in the survey, we justify the limits chosen for the classification here. Although specialists put the optimum between 15 and $20^{\circ} \mathrm{C}$, during the summer it is possible for situations to be tolerable up to $28.5^{\circ} \mathrm{C}$. This is why compressed THI values between 15 and $28.5^{\circ} \mathrm{C}$ are established for Types 1, 2, 5, and 6. Good weather that is hot (Type 3) admits values between 20 and $28.5^{\circ} \mathrm{C}$ and good cool weather (Type 4 ) between 15 and $26.6^{\circ} \mathrm{C}$.

\subsection{Limitations of the method}

When trying to define ideal climate-meteorological conditions for the average tourist who visits Catalonia, in order to contrast them with real weather and thus evaluate the tourist potential of present Catalan climates, various difficulties appear that make it necessary to adjust some of the results:

- The objectives of the proposal try to center on what is called the period of recreational activity, the time during which tourists do the majority of their activities and which, for the area of study, is considered to be between 10:00 and 18:00 h. This is reflected in the survey used to identify ideal conditions. When this was compared with real weather using the different types, it turned out that the organization responsible for supplying the data, the National Institute of Meteorology, did not provide hourly data (although it does exist). Thus in some cases it was necessary to limit the scope of the study to the data available.

- Although there are 6 fundamental parameters of interest in the proposed classification, only 4 are included in the survey (sun, duration of precipitation, maximum air temperature, and wind speed), since it is hard for the survey population to define thresholds for the other two (Thom's thermo-hygrometric index and Siple \& Passel's thermo-anemometric index) in specific terms. The comfort indexes used are not the most appropriate for the season chosen for analysis (the summer), nor are they the most complete. We are aware of the advances made in this field of bioclimatology, but many of the new formulae proposed require data that we were unable to obtain from the government agencies with the time information that our study required.

- As a quantitative technique, the survey is limited by respondents' inability to perceive phenomena in all of their complexity. Tourists see weather as an entirety; however, in the questions the variables are treated separately and then extrapolated afterwards. The most useful thresholds combine to describe the types of favorable weather at various levels; the least valuable describe the types of weather that completely spoil tourist activity.

- We start from the premise that tourists have more or less stereotyped climate-meteorological preferences that can be determined by a survey. If this is true, it is necessary to consider the difficulty of asking questions about thresholds for different atmospheric conditions, because of the subjectivity that the very process of feeling implies, since it can be influenced by various circumstances (mood, atmospheric conditions during survey implementation, etc.).

- Finally, it is worth noting that the validation system (pretest) was useful for discarding questions that were not understood or that proved to be unnecessary because of the clarity or homogeneity of the results. This part of the research project, which provided interesting information, is not described in depth in this article for reasons of space.

In spite of the limitations, the use of types of weather along with the survey was the most appropriate option. The method using types of weather offers considerable advantages because it is based on real weather conditions and is thus less abstract than methods based on the simple calculation of climatic indices. Furthermore, this approach rejects the exclusive use of just 1 climate element or of average values (which do not provide a good representation of Catalan and Spanish weather), and it uses daily data that are real and specific for the tourist. The survey is valuable because it incorporates the preferences shown by the tourists themselves during their stay at the destination. This makes it possible to discover tourist preferences in a direct way and also provides information on tolerance levels by detecting discrepancies between the desired temperature and the 'real weather' at the chosen destination.

\subsection{Data}

To evaluate the climate potential in Catalonia in terms of types of weather we relied on a network of 11 first-order National Institute of Meteorology observatories that were distributed by tourist zones and were representative of the zones in which they were located. Tourist zones of Catalonia have been established by the Departament de Comerç, Turisme i Consum de la Generalitat de Catalunya, and they are units for tourist management. In this paper the tourist zones are Costa Brava, Costa del Maresme, Barcelona, Costa del Garraf, Costa Daurada, Terres de l'Ebre, Terres de Lleida, Catalunya Central, Pirineus Pre-Pirineus and Val d'Aran. The information generated in each observatory year by year for 1970-1990 by recording daily maximum air temperatures $\left({ }^{\circ} \mathrm{C}\right)$, sunshine for the 
0-24 $\mathrm{h}$ period, precipitation for the $0-24 \mathrm{~h}$ period $(\mathrm{mm})$, relative humidity at 13:00 h (\%), and wind speed at 13:00 h $\left(\mathrm{m} \mathrm{s}^{-1}\right)$ constituted the numerical base for this task. We have applied the classification to our series day to day and year after year, following calculation using the Thom thermo-hygrometric index (1959), the Siple \& Passel thermo-anemometric index (1945), and the duration of rainy periods following Martín \& Peña (2001). The method was applied at the various observatories on a fixed period of time (April-November). This period was established on the basis of calculations of the duration of the summer tourist season based on the maximum air temperatures recorded in 22 observatories (Fig. 4; Gómez-Martín 2003).

In contrast, the variables used to evaluate demand behavior in terms of temporal and spatial distribution were the number of visitors and the occupation rate for tourist accommodation. This information was supplied by the National Statistics Institute with monthly periodicity for zones and localities that were appropriate for our purposes.

\section{RESULTS AND DISCUSSION}

The study of demand climate preferences is a basic step toward the preparation of a catalog of types of weather that are suitable for tourism, which, when contrasted with real weather in the present, would facilitate evaluation of tourism potential. This evaluation of the Catalan climate's tourism potential is based on data from existing first-order observatories, and the results are shown on frequency calendars of the different types of daily weather from 1970-1990 (Gómez-Martín 2004). The most attractive categories are at the base and ordered in grades; the least appropriate categories are at the top. Although the calculations are done on a daily basis, given the changing, variable, and irregular weather in Catalonia, I have chosen to use a 10 d scale (see, for example, Fig. 5).

The analysis of climate characteristics and subsequent contrast with tourism in the area of study, in terms of number of visitors and the occupation rates, provides some important information, as detailed in the following.

- In general terms, the climates of Catalonia meet the demands of the average tourist from 31 to $61 \%$ of the summer (April-November), in other words, about 3 to 6 d out of every 10. The lowest values (about 30\%) correspond to the highest mountain areas or to places with medium altitude and marked continentality (about 40-45\%). Highest preferences are for locations on the coast, where the Mediterranean has a moderating effect on weather conditions (about 55-61\%). The middle registers correspond to areas in the interior, not very far from the littoral and not very high above sea level (about 45-55\%). In general terms, the spatial distribution of demand and tourism supply show a significant correspondence with climate suitability. Visitor flows and tourist infrastructures are mainly concentrated on the Catalan coast.

- In the northern part of Catalonia, the summer season is shorter and the evaluation of the tourist potential of the climate is less favorable in the intermediate (May, June, September, and October) and extreme months (April and November) of the period of analysis, though this is more or less modified depending on the level of continentality. The opposite happens in the southern part. The summer season is longer (it could go beyond the months of April and November), and weather during the intermediate and extreme months is also more favorable. The analysis of tourist visits and the occupation rate for tourist accommodation shows a correspondence with this data. Tourist areas in the southern part of Catalonia prolong the season beyond the traditional summer months with greater success than tourist areas in the north. In any case, the rates of occupation are low in comparison with the favorable level of weather conditions.

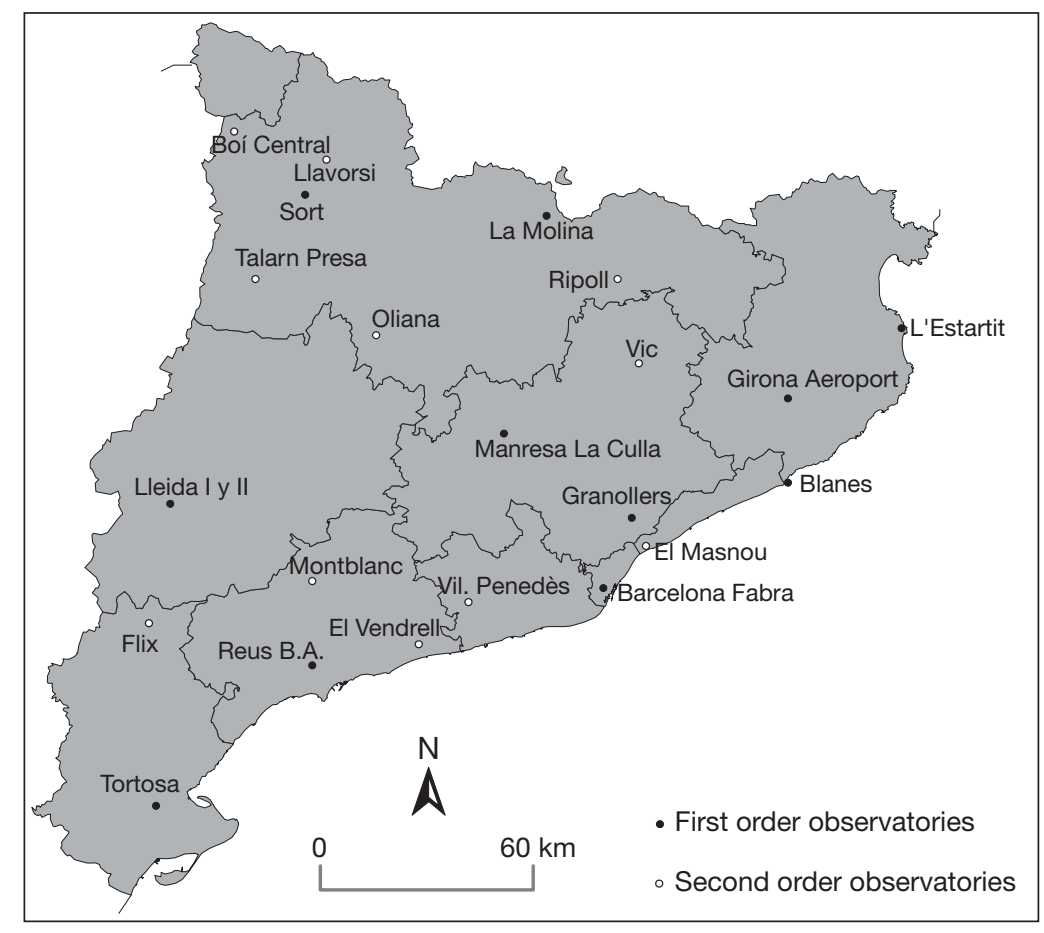

Fig. 4. Locations of the first-order and second-order climate observatories 

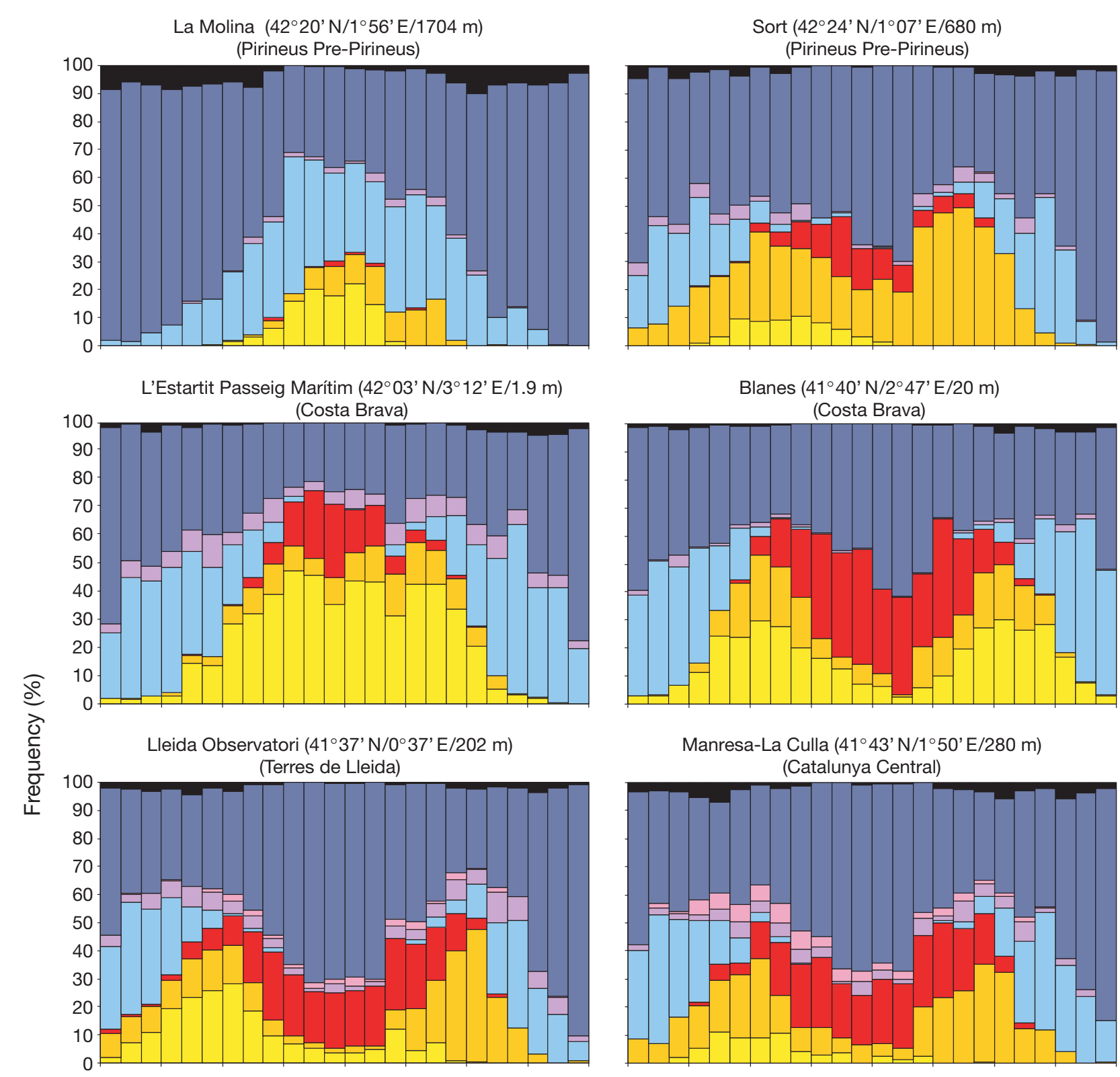

Tortosa Observatori de l'Ebre $\left(40^{\circ} 49^{\prime} \mathrm{N} / 0^{\circ} 29^{\prime} \mathrm{E} / 50 \mathrm{~m}\right)$ (Terres de l'Ebre)
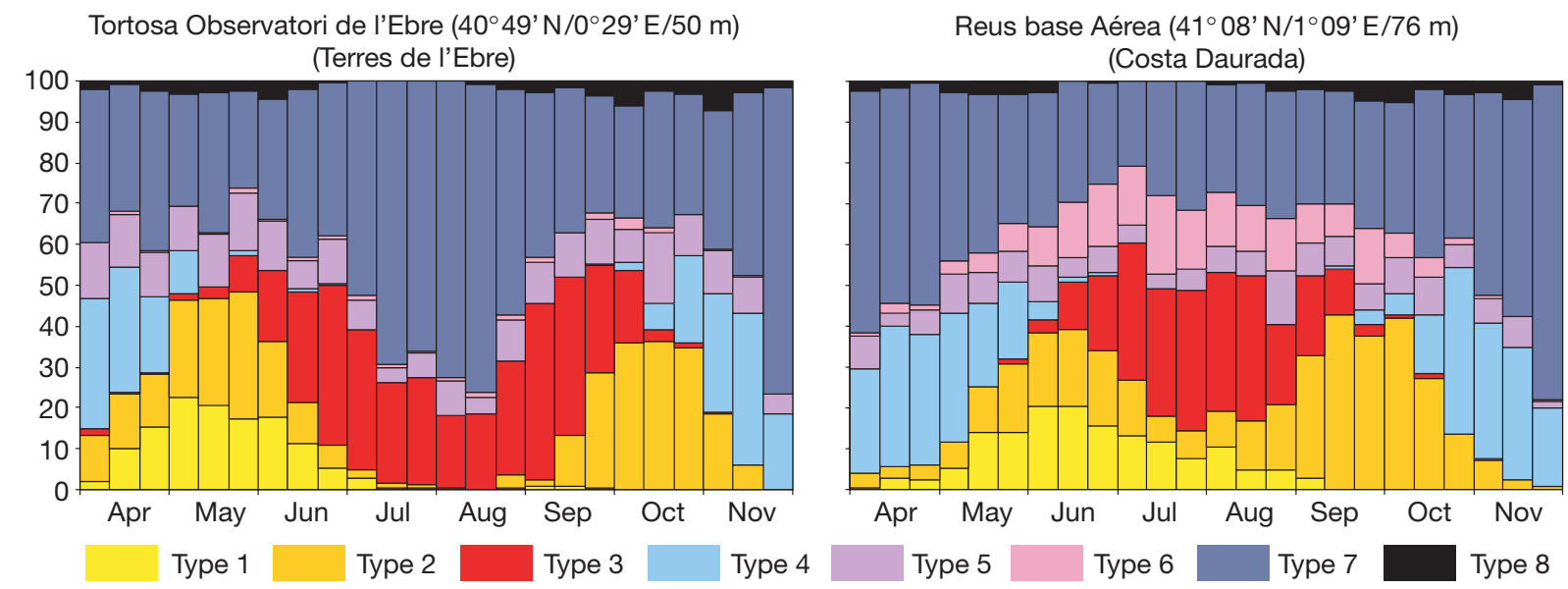

Fig. 5. Calendars showing the percentage distribution of summer weather types for $10 \mathrm{~d}$ periods (1970-1990) 
- A good part of the observations of the study shows better climate conditions for tourism in the intermediate and extreme months at the end of the summer than at the beginning, and finds a notable correspondence with the presence of tourists. In any case, the visitation rates are low in comparison with the high level of suitability.

- Although geographical location further to the south is associated with, in general terms, a greater tourism potential in the intermediate months and the extremes of the summer season, it also causes inconvenience in the middle of the summer (July and August). The steep angle of the sun's rays and increased subtropical influences cause air temperatures to rise and reduce suitability for tourism because of excessive heat. In coastal areas problems are caused by the combination of air temperature and high ambient humidity (sticky heat); in the interior, they are caused by dry heat and the negative cooling power of the air.

It is at this point that one detects a certain discrepancy between suitability and visitation, since the latter is very high during the middle months. This lack of fit suggests a number of interesting points, as addressed in the following.

Incidence of other factors that affect demand behavior. The temporal and spatial allocation of tourists depends not only on the destination's atmospheric conditions but also on other aspects, such as greater or lesser work flexibility, climate conditions at the places of origin, the school calendar, the presence of other resources and factors that attract tourist attention, and price, to give just a few examples. In this sense, it is worth noting that although studies that deal with tourist demand are numerous there are not so many that deal specifically with the importance that atmospheric variables take on in the rates of tourist visits to some destinations, or that determine how those climate aspects figure in important attraction factors for demand (Barry \& O'Hagan 1972, Hu \& Ritchie 1993, Syriopoulos \& Sinclair 1993, Shoemaker 1994, Lohmann \& Kaim 1999, Maddison 2001, Lise \& Tol 2002, Hamilton 2004). This is why studies are needed that, bearing other variables in mind, estimate the real importance and weight that atmospheric conditions have on the tourist-consumer's purchase process (choice of destination and duration of stay). The results can help interpret the temporal and spatial distribution of demand with greater precision and, at the same time, be useful in the development of projections for possible climate-change scenarios.

Mismatching between the regional and/or local climatic conditions and internal and external microclimates where tourists pursue a significant part of their activities. Tourism climatology studies use observation networks established by state organizations, which reflect regional and/or local climatic conditions but have little to do with the natural or artificial microclimates in which tourists pursue their activities, which are almost always closer to their preferences. This is why multi-scale climate-tourism studies that complement traditional regional and local analysis with studies done at a micro-scale are more and more necessary. The introduction of this level of analysis gives tourism planners a greater capacity to create environments that meet the preferences expressed by the demand.

Tolerance, on the part of demand, of climate conditions slightly different from those preferred. The differences between the atmospheric conditions desired by the tourist demand and the destination actually chosen by that demand show that, although tourists show certain preferences, their behavior has flexibility thresholds. In the chosen zone, the results of the pretest and the survey reflect greater tolerance for higher temperatures and less for the presence of wind or heavy rains. In effect, in a good part of the area of analysis, the lesser climate potential in the middle of the summer is related to the presence of higher air-temperature values and not to strong winds or long episodes of precipitation. In this sense, detailed studies are required to precisely determine the level of physiological and psychological (or external) tolerance for climatemeteorological conditions that differ from those preferred or desired.

Influence of climate information provided tourists. The analysis of the climate information provided tourists shows that, in the cases of Spain and Catalonia, it has traditionally combined idyllic descriptions and numerical averages that create an idealized view and an idea of temporal and spatial uniformity of the climate that may mislead tourists (Gómez-Martín $1999 a, b)$. Thus it is necessary to improve the quantity and quality of the information, since satisfaction of the demand is attributable, in part, to 2 interconnected variables: the climate-meteorological conditions and the information about themselves that is provided the tourist. A satisfied visitor tends to return to a tourist destination, but an unsatisfied tourist tends to change his selection (Perry 1993, De Freitas 2003, GómezMartín 2005).

The study of present climate suitabilities and the behavior of tourists reveal several uncertain aspects that should be studied. However, at the same time, they offer several indications for management strategies that would make it possible to improve opportunities for the tourist sector now. At present, in the cases of Spain and Catalonia, full advantage is not being taken of the opportunities offered by the climate for tourism. The periods of time and places identified as 
climatically suitable for tourism are more extensive than the periods and areas actually used. This is why the agents and operators in the market must act on the demand, on the geographical-tourist space, and on the supply to foment taking advantage of this resource. Tourists should be provided with detailed climate information. The calendars proposed for this purpose should supply real information that can be useful for planning vacations. At the same time, demand should also be acted upon, particularly for certain market niches such as retirees and younger tourists, with offers that can help obtain a better temporal and spatial distribution of the tourists in the area of study. It is also necessary to incentivize the adaptation or creation of new products and activities during the favorable climate periods with the objective of promoting the deseasonalization of the sector. Planning agents should also focus on the creation of environments or microclimates more suited to the preferences of tourists during the lessfavorable periods.

\section{FINAL REMARKS}

The reports completed up to now (Viner \& Agnew 1999, IPCC 2001, Ministerio de Medio Ambiente \& Oficina Española de Cambio Climático 2005) indicate, for our area of study, significant climate changes that will have an impact of greater or lesser intensity on natural, human, and economic systems. Tourism is expected to be one of the sectors most seriously affected, which is why it is worth resolving some of the questions that have been brought up, since this could assist in the adoption of steps that will make it possible to adjust to these changes. The Spanish and Catalan tourist systems have a proven capacity to adapt. These are dynamic systems that are capable of generating responses, particularly since the changes take place slowly and thus allow for the possibility of planning and taking effective action in the system in order to counteract the possible effects.

Generally, when looking at climate-change scenarios, the impact on future climate potential for tourism and resulting effects on demand have been considered. Some authors (Scott \& McBoyle 2001, Amelung \& Viner 2003, Morabito et al. 2004) have provided projections, employing methods differing from those shown here and obtaining results that were not at all encouraging for the industry. The proposal offered in this work could also be used to do an analysis of the potential of locations and periods of time that are more or less suitable for tourism according to certain indicators. In any case, all of these projections and the corresponding results should be taken with certain reservations given the following.
The analysis of potential is made using preferences that tourists today show with regard to climate. We should bear in mind, however, that the resource involved in a product is not immune to the effects of fashion and that its value can thus vary in time depending on social changes. Nobody can guarantee that the preferences and evaluations that tourists show today with respect to climate will be the same in the future.

The analyses of the potential are made without considering the thresholds of physiological and psychological (or external) tolerance of tourists for certain atmospheric conditions. This is why we need to make progress in our understanding of this subject in order to be able to include it as a corrector.

We do not know the elasticity of demand when different variables such as climate, price, and income per capita interact.

The spatial resolution of the climatic models is still too low to be able to reproduce orographic and coastal details that decisively determine the climate on a regional and local scale in the area of study and that are of great interest for tourist climatology.

In the same way, the analyses of the potential are made without considering the impacts that microclimatic aspects introduce, which could help us too see the results in perspective.

Acknowledgements. This work was sponsored by the Spanish Ministry of Science and Technology with the grant SEJ200507389/GEOG.

\section{LITERATURE CITED}

Agnew M, Viner D (2001) Potential impacts of climate change on international tourism. Int $\mathrm{J}$ Tourism Hospitality Res $3(1): 37-60$

Amelung B, Viner D (2003) Scorchio! Tourist comfort in the Mediterranean. Exploring the future with the tourism climatic index. In: NATO Advanced Research Workshop. Climate change and tourism: Assessment and coping strategies. ICIS and the Polish Academy of Science, Warsaw

Auliciems A (1976) Weather perception: a subtropical winter study. Weather 9:312-316

Auliciems A (1978) Mood dependency on low intensity atmospheric variability. Int J Biometeorol 1:20-32

Barry K, O'Hagan J (1972) An econometric study of British tourist expenditure in Ireland. Econom Soc Rev 3:143-161

Besancenot J (1985) Climat et tourisme estival sur les côtes de la Peninsule Ibérique. Rev Geogr Pyrenees Sud-Ouest 4:427-449

Besancenot J (1991) Clima y turismo. Masson, Barcelona

Besancenot J, Mounier J, De Lavenne F (1978) Les conditions climatiques du tourisme littoral: un méthode de recherche compréhensive. Noris 99:357-382

Campbell DE, Beets JL (1977) Meteorological variables and behaviour: an annotated bibliography. JSAS Catalogue of Selected Documents in Psychology 7, 1

Cunningham MR (1979) Weather, mood and helping behav- 
iour: quasi experiments with the sunshine Samaritan. J Persona Soc Psychol 11:1947-1956

De Freitas C (2001) Theory, concepts and methods in tourism climate research. In: Matzarakis A, De Freitas C (eds) Proceedings of the First International Workshop on Climate, Tourism and Recreation. Int Soc Biometeorol, Norman, OK, p 3-20

De Freitas C (2003) Tourism climatology: evaluating environmental information for decision making and business planning in the recreation and tourism sector. Int J Biometeorol 48(1):45-54

Escourrou P (1980) Climat et tourisme sur les côtes françaises de Dinard à Biarritz. $\mathrm{PhD}$ thesis, Université de Paris I

Estudis de Turisme de Catalunya (2004) Dades bàsiques, 2003. Generalitat de Catalunya, Departament de Comerç, Turisme i Consum, Barcelona

Gómez-Martín Mª (1999a) Imagen turística, calidad medioambiental y clima: los folletos turísticos catalanes. In: EQUIP (eds) Paisaje y turismo. Publicaciones Universitat de Barcelona, Barcelona, Vol II, p 285-303

Gómez-Martín Mª B (1999b) El Clima como activo del turismo: los folletos turísticos catalanes. In: El territorio y su imagen. Publicaciones Universidad de Málaga y Consejería de Medio Ambiente de la Junta de Andalucía, Málaga, Vol I, p 515-526

Gómez-Martín Må (2000) Clima y turismo en Cataluña: evaluación del potencial climático-turístico de la estación estival. PhD thesis, Universidad de Barcelona

Gómez-Martín Mả (2003) Duración y características de la estación climático-turística estival en Cataluña. Estudios Geográficos 253:623-654

Gómez-Martín Mª (2004) An evaluation of the tourist potential of the climate in Catalonia (Spain). A regional study. Geog Ann A 86(3):249-264

Gómez-Martín $\mathrm{M}^{\mathrm{a} B}$ (2005) Weather, climate and tourism. A geographical perspective. Ann Tourism Res 32(3):571-591

Hamilton J (2004) Climate and the destination choice of German tourists. Nota di Lavoro 21.2004, Fondazione Eni Enrico Mattei, Milan

Hu Y, Ritchie JR (1993) Measuring destination attractiveness: a contextual approach. J Travel Res 32(2):25-34

Instituto de Estudios Turísticos (2004a) Movimientos turísticos en fronteras (FRONTUR). Ministerio de Economía, Madrid

Instituto de Estudios Turísticos (2004b) Movimientos turísticos de los españoles (FAMILITUR). Ministerio de Economía, Madrid

IPCC (2001) El tercer informe de evaluación: cambio climático 2001. Organización Mundial de Meteorología \& Programa de Naciones Unidas para el Medio Ambiente, Ginebra

Lise W, Tol R (2002) Impact of climate on tourist demand. Clim Change 55(4):429-449

Lohmann M, Kaim E (1999) Weather and holiday destination preferences: images, attitude and experience. Tourist Rev 2:54-64

Maddison D (2001) In search of warmer climates? The impact of climate change on flows of British tourists. Clim Change 49:193-208

Martín J, Peña JC (2001) Duración de las precipitaciones y cantidad de agua precipitada: adaptación de las series de precipitación diarias catalanas (documento inédito). Universidad de Barcelona

Editorial responsibility: Otto Kinne, Oldendorf/Luhe, Germany
Ministerio de Medio Ambiente, Oficina Española de Cambio Climático (2005) Evaluación preliminar de los impactos en España por efecto del cambio climático. Publicaciones del Ministerio de Medio Ambiente, Madrid

Morabito M, Crisci A, Barcaioli G, Maracchi G (2004) Climate change: the impact on tourism comfort at three Italian tourist sites. In: Matzarakis A, De Freitas C, Scott D (eds) Advances in tourism climatology. Berichte 12 des Meteorologischen Institutes der Universität Freiburg

Perry A (1993) Climate and weather information for the package holiday-maker. Weather 48(12):410-414

Perry A (2000) Impact of climate change on tourism in the Mediterranean: adaptive responses. Nota di Lavoro. FEEM, Milan. (Paper presented at the International Workshop on Climate Change and Mediterranean Coastal Systems: Regional Scenarios and Vulnerability Assessment. Istituto Veneto di Scienze, Lettere ed Arti, Venice, 9-10 December)

Perry A (2001) More heat and drought - can Mediterranean tourism survive and prosper? In: Matzarakis A, De Freitas CR (eds) Proceedings of the First International Workshop on Climate, Tourism and Recreation. Int Soc Biometeorol, Norman, OK, p 35-40

Perry A (2005) The Mediterranean: how can the world's most popular and successful tourist destination adapt to a changing climate? In: Hall MC, Higham J (eds) Tourism, recreation and climate change. Aspects of Tourism 22. Channel View Publications, Clevedon

Scott D (2003) Climate change and tourism in the mountain regions of North America. In: First International Conference on Climate Change and Tourism, Djerba, Tunisia, 9-11 April 2003, World Tourism Organization

Scott D, McBoyle G (2001) Using a modified tourism climate index to examine the implications of climate change for climate as a natural resource for tourism. In: Matzarakis A, De Freitas CR (eds) Proceedings of the First International Workshop on Climate, Tourism and Recreation. Int Soc Biometeorol, Norman, OK, p 69-88

Shoemaker S (1994) Segmenting the US travel market according to benefits realized. J Travel Res 32(3):8-21

Siple PA, Passel CF (1945) Measurements of dry atmospheric cooling in subfreezing temperatures. Proc Am Philos Soc 1:177-199

Syriopolous T, Sinclair T (1993) An econometric study of tourism demand: the AIDS model of US and European tourism in Mediterranean countries. Appl Econ 25: $1541-1552$

Terjung WH (1966) Physiologic climates of the conterminous United States: a bioclimatic classification based of man. Ann Assoc Am Geogr 56:141-179

Thom EC (1959) The discomfort index. Weatherwise XX: $57-60$

Viner D, Agnew M (1999) Climate change and its impacts on tourism. Report prepared for WWF-UK, Climatic Research Unit, University of East Anglia, Norwich

Winslow CEA, Herrington LP (1935) Subjective reactions of human beings to certain outdoor atmospheric conditions. Heat Piping Air Condition J VII:551-556

World Tourism Organization (2004) Datos esenciales. Edición 2004. OMT (Organización Mundial de Turismo), Madrid

Submitted: June 29, 2005; Accepted: February 16, 2006

Proofs received from author(s): June 16, 2006 